\title{
Comparative proteome analysis of Tumor necrosis factor a-stimulated human Vascular Smooth Muscle Cells in response to melittin
}

\author{
Hyun-Ji Cho ${ }^{1 \dagger}$, Jeong-Han Kang ${ }^{2+}$, Kwan-Kyu Park', Jung-Yoon Choe ${ }^{1}$, Yoon-Yub Park', Yong-Suk Moon ${ }^{1}$, \\ Il-Kyung Chung ${ }^{3}$, Hyeun-Wook Chang ${ }^{4}$, Cheorl-Ho Kim ${ }^{5}$, Yung Hyun Choi ${ }^{6}$, Wun-Jae Kim7, Sung-Kwon Moon ${ }^{8}$ \\ and Young-Chae Chang ${ }^{1 *}$
}

\begin{abstract}
Background: Bee venom has been used to relieve pain and to treat inflammatory diseases, including rheumatoid arthritis, in humans. To better understand the mechanisms of the anti-inflammatory and anti-atherosclerosis effect of bee venom, gel electrophoresis and mass spectrometry were used to identify proteins whose expression was altered in human Vascular Smooth Muscle Cells (hVSMCs) stimulated by tumor necrosis factor alpha after $12 \mathrm{~h}$ in the presence of melittin.

Results: To obtain valuable insights into the anti-inflammatory and anti-atherosclerosis mechanisms of melittin, two-dimensional (2-D) gel electrophoresis and MALDI-TOF/TOF were used. The proteome study, we showed 33 significant proteins that were differentially expressed in the cells treated with tumor necrosis factor alpha and melittin. Thirteen proteins were significantly increased in the cells treated with tumor necrosis factor alpha, and those proteins were reduced in the cells treated with melittin. Five of the proteins that showed increased expression in the cells treated with tumor necrosis factor alpha are involved in cell migration, including calreticulin, an essential factor of development that plays a role in transcription regulation. The proteins involved in cell migration were reduced in the melittin treated cells. The observed changes in the expression of GRP75, prohibitin, and a select group of other proteins were validated with reverse transcribed-PCR. It was confirmed that the observed change in the protein levels reflected a change in the genes level. In addition, the phosphorylation of EGFR and ERK was validated by analyzing the protein pathway.
\end{abstract}

Conclusion: Taken together, these data established that the expression of some proteins was significantly changed by melittin treatment in tumor necrosis factor alpha stimulated the cells and provided insights into the mechanism of the melittin function for its potential use as an anti-inflammatory agent.

\section{Background}

The migration and proliferation of human Vascular Smooth Muscle Cells (hVSMCs) are the major causes of the development of advanced lesions in atherosclerosis [1]. The migration and proliferation of hVSMCs is caused by pathological phenomena such as the accumulation of inflammatory cells and the release of pro-

\footnotetext{
*Correspondence: ycchang@cu.ac.kr

${ }^{\dagger}$ Equal contributors

'Research Institute of Biomedical Engineering and Department of Medicine, Catholic University of Daegu School of Medicine, Daegu 705-718, Republic of Korea

Full list of author information is available at the end of the article
}

inflammatory cytokines [1,2]. Pro-inflammatory cytokines such as the tumor necrosis factor (TNF)- $\alpha$ have various acts that mediate inflammation, and atherogenesis. Especially, TNF- $\alpha$ is a cytokine that is involved in systemic inflammation. Thus, the primary role of TNF- $\alpha$ is the regulation of immune cells. Moreover, TNF- $\alpha$ can induce apoptotic cell death, and inhibit tumorigenesis and viral replication [3]. On the other hand, the dysregulation of TNF- $\alpha$ production has been implicated in several of human diseases, as well as in atherosclerosis and cancer [2]. Therefore, hVSMCs and TNF- $\alpha$ decisively promote atherosclerosis and inflammation.

\section{Biomed Central}

(c) 2013 Cho et al.; licensee BioMed Central Ltd. This is an Open Access article distributed under the terms of the Creative Commons Attribution License (http://creativecommons.org/licenses/by/2.0), which permits unrestricted use, distribution, and reproduction in any medium, provided the original work is properly cited. 
Bee venom (BV) is known as a very complex mixture of active peptides that include melittin, phospholipase A2, apamin, adolapin, hyaluronidase, dopamine, and the protease-inhibitor. It has been used in many studies on the biological and pharmacological activities that have anti-inflammatory effects on rheumatoid arthritis [4,5]. In addition, BV affects pain release, and immune modulatory activity [6]. It has also, been reported to have induced apoptosis and suppressed the signaling pathway in leukemic cells and renal cancer $[7,8]$. The major compound of BV is melittin, a 26 amino acid peptide, which forms an amphipathic helix with a highly charged carboxyl terminus [9]. It comprises $52 \%$ of BV peptides [10]. Melittin reportedly has multiple effects, such as antibacterial, antivirus, and anti-inflammatory effects, in various cell types $[11,13]$. In addition, it has been reported to be capable of cell cycle arrest, growth inhibition, and apoptosis in various tumor cells $[12,13]$. However, the mechanisms of the anti-atherosclerosis and anti-inflammatory effects of melittin have not yet been fully explained. Thus, the proteomics method was used to understand the mechanisms of melittin in inflammation-induced hVSMCs. Such studies can be facilitated by comparing the obtained gels, with the 2-DE reference gels representing the typical pattern of the cells being studied under normal conditions. The association of 2-D electrophoresis with MALDI-TOF-TOF mass spectrometry and database interrogations enabled the identification of 33 proteins that were differentially expressed in the hVSMCs after melittin treatment. In particular, various proteins were implicated in the inflammation, regulation of the protein folding, oxidation reduction, and signal transduction.

\section{Results}

\section{Detection of the differentially expressed proteins in the hVSMCs}

To determine the changes in the protein expression after the treatment of the cells with TNF- $\alpha$ or melittin, we used 2-D gel electrophoresis to separate the total cell proteins from the hVSMCs. Each gel was loaded with $400 \mu \mathrm{g}$ of protein. Approximately 1,000 individual spots were resolved in this manner. It was expected that many individual spots would contain more than one protein and this was borne out by the subsequent analysis using mass spectrometry. It was also found in a number of instances that the same protein was present in multiple spots and was most likely the product of the posttranslational modifications or alternative splicing at the mRNA level. Nevertheless, an estimated 900 individual proteins at least were resolved, which provided a representative samples of the cellular proteins and allowed identification of many differentially expressed proteins.
Three gels per sample were processed simultaneously and analyzed with PDQUEST 2-D software to quantitatively compare the proteins that were recovered from the treated cultures with those from the untreated cells. Figure $1 \mathrm{~A}$ and $\mathrm{B}$ show enlarged views of the gel regions that contained spots whose staining intensity was, significantly increased and decreased, respectively, after the TNF- $\alpha$ or melittin treatment.

\section{Identification of the differentially expressed proteins with MS}

The protein spots from the 2-D gels were subjected to trypsin digestion and MALDI-TOF-TOF analysis. Protein was definitively identified in 33 of the 52 spots that showed significant changes, after the melittin treatment. Several proteins were identified multiple times because they were present in more than one spot. Table 1 lists the proteins with the significantly differential expressions, which had staining intensity ratios in the samples from the treated and untreated cells were $\geq 1.5$ or $\leq 0.6$. More than $95 \%$ of the spots had more than $10 \%$ sequence coverage and were identified with a 95\% confidence level. The identities of many of the proteins were further validated by the agreement between their apparent molecular weights and the isoelectric points that were estimated from the positions of the identified proteins in the 2-D gels and their theoretical values $\left(\mathrm{M}_{\mathrm{r}}<20 \%\right.$ or $\left.\mathrm{pI}<0.5\right)$.

The proteins were classified according to their molecular functions using the Panther Classification System (www.pantherdb.org) and according to their categories based cellular locations using the classifications from the Swiss-Prot/TrEMBL protein knowledge base. The distribution of the proteins into the different classes is depicted in the bar graph in Figure 2A. The functional categories with the highest representativeness were transferase $(\sim 18 \%)$, the enzyme modulator $(17 \%)$, and oxidoreductase (10\%). In addition, $65 \%$ of the proteins were localized in the cytoplasm (Figure 2B).

\section{Protein pathway analysis of the differential expression protein in the TNF- $a$ treated cells}

To provide some insights into the cellular activities that were affected by the TNF- $\alpha$ or melittin treated cells, a pathway analysis was performed to place the proteins into different functional networks. As shown in Figure 3A, the 22 proteins that are involved in lipid metabolism, small molecule biochemistry and cellular movement were grouped together. In addition, the 11 proteins that are involved in developmental disorder, skeletal and muscular disorders, and cancer were grouped together (Figure 3B). Therefore, selected IPA results were validated using biochemical techniques. 


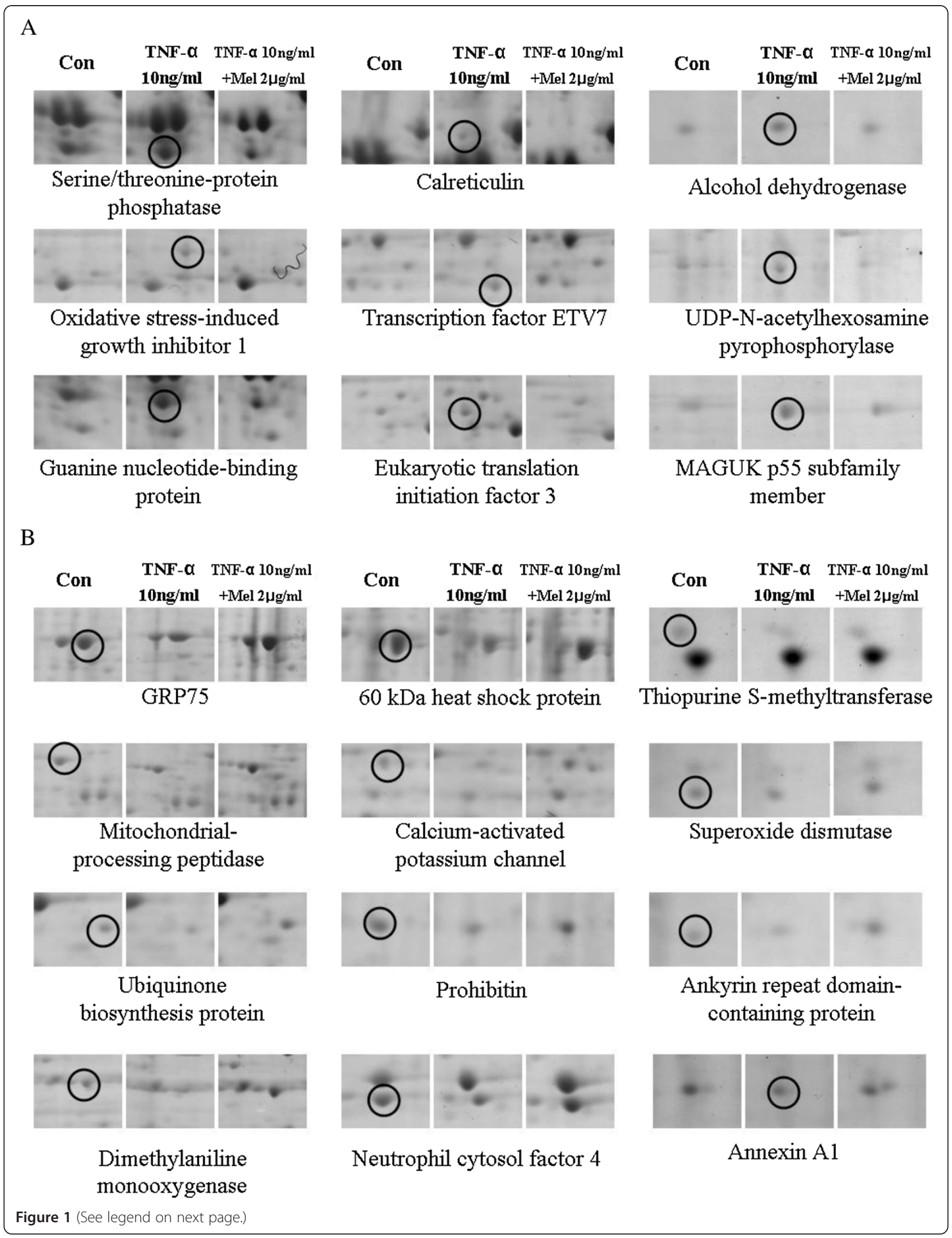


(See figure on previous page.)

Figure 1 Expression of select proteins in hVSMCs following treatment with TNF-a or melittin. Whole cell extracts (400 $\mu$ g of protein) were prepared from hVSMCs cultured with TNF-a or melittin. Proteins from each culture were separated in parallel by two-dimensional SDS-PAGE. Enlarged images of the spots containing proteins with increased expression in TNF-a-treated cells are shown in panel $\boldsymbol{A}$; images of spots containing proteins with decreased expression in melittin-treated cells are shown in panel $\boldsymbol{B}$.

\section{Validation of the selected proteins by with RT-PCR}

To confirm the changes in the protein expression after the melittin treatment, RT-PCR analysis was performed to measure the changes in the corresponding mRNAs. As shown in Figure 4A, the levels of four genes were reduced when the cells were treated with TNF- $\alpha$ and the levels of all these four genes increased when melittin added. Additionally, the mRNA expressions of prohibitin and HSP60 did not change when only melittin added. The expressions of GRP75 and annexin 1 increased more significantly than those of the non-stimulated cells, however, when only added with melittin (Additional file 1A). In contrast, the level of calriticulin was increased in the TNF- $\alpha$ treated cell and did not change when cells were treated with melittin (Additional file 1A). The mRNA measurements confirmed that the changes were observed by staining following the 2-D gel electrophoresis reflected changes in the protein levels. The analysis of the protein pathway in the melittin-treated cells also showed the phosphorylation of EGFR, and ERK and the expression of NF-kB. As shown in Figure 4B, the melittin treatment reduced the phosphorylation of EGFR, and ERK and the expression of NF- $\mathrm{KB}$ in nuclear. Moreover, they were reduced more significantly than the cells that were not-stimulated cells by melittin (Additional file 1B). Therefore, it is suggested that melittin blocks the level of genes and the activity of kinases.

\section{Discussion}

BV has been widely used to relieve pain and treat inflammation in various chronic inflammatory diseases, such as rheumatoid arthritis and multiple sclerosis. A major compound of $\mathrm{BV}$, melittin is the principal active component of $\mathrm{BV}$ and is a powerful stimulator of phospholipase A2. It also inhibits various protein kinases and is a cell membrane lytic factor. It has also shown potent anti-microbial activity and suppression of infections $[14,15]$.

In this study, a proteomics analysis of hVSMCs treated with TNF- $\alpha$ or melittin was first performed to identify differentially expressed proteins that are highly affected by melittin in TNF- $\alpha$ stimulated cells. This technique revealed 52 differentially expressed proteins and identified 33 significantly differentially expressed proteins whose expressions had consistently different patterns after TNF- $\alpha$ or melittin treatment. Many of the identified proteins were Stress-70 protein and Annexin A1, which are involved in anti-apoptosis.

Prohibitin 1 (PHB) is multifunctional protein that is localized in cells and mitochondrial membranes as well as in the nucleus $[16,17]$. It is implicated in cellular processes such as the mitochondrial function and protein folding [18], transcription regulation [19] and proliferation control and suppression of oncogenesis [20,21]. Expression of $\mathrm{PHB}$ decreases during ulcerative colitis and Crohn's disease, two forms of inflammatory bowel disease [22,23]. In this study, prohibitin expression was down-regulated in TNF- $\alpha$ treated cells and up- regulated in melittin treated cells.

Annexins have been diversely implicated in cell differentiation and proliferation, extracellular processes such as coagulation, and membrane fusion events such as endocytosis and exocytosis [24]. In addition, annexins are intracellular molecules that are implicated in the down-regulation of inflammation. Annexin-1 was identified recently as a secreted molecule and suggested as a potent inhibitor of inflammation both in vitro, and in vivo. Studies have indicated that annexin-1 is secreted, and subsequent reports have shown that secreted annexin-1 participates in additional anti-inflammatory effects such as detachment of neutrophils from the vascular endothelium [25,26]. In this study, annexin-1 expression was restored in melittin-treated hVSMCs and melittin was suggested as having anti-inflammatory effects.

Calreticulin binds unfolded glycosylated proteins in the ER and is implicated in many cellular functions such as lectin-like chaperoning, $\mathrm{Ca}^{+}$storage and signaling, regulation of gene expression, cell adhesion, wound healing and auto-immunity. Its over-expression on the surface of lung fibroblasts has been reported in response to cytomegalovirus infection [27,28]. Calreticulin was up-regulated by TNF- $\alpha$ and down-regulated in the melittin-treated hVSMCs.

\section{Conclusion}

This is the first report of the proteomic analysis of the effects of melittin treatment on cultured hVSMCs. In this study, the anti-inflammatory mechanism of melittin on the inflammatory process was discovered. And several target molecular of inflammation and proliferation such as prohibitin, annexin-1 and calreticulin were identified. In addition, we found that two major protein pathways using bioinformatics method. The protein 
Table 1 Proteins showing differential expression in hVSMCs in response to melittin

\begin{tabular}{|c|c|c|c|c|c|c|c|c|c|}
\hline & ${ }^{a}$ AC No & Protein & Localization & Function & ${ }^{b}$ Score & MW & PI & $\begin{array}{l}\text { TNF/ } \\
\text { Con }\end{array}$ & $\begin{array}{l}\text { MEL }+ \\
\text { TNF/Con }\end{array}$ \\
\hline 1 & Q15257 & $\begin{array}{l}\text { Serine/threonine-protein phosphatase } \\
2 A \text { regulatory subunit }\end{array}$ & C & Apoptosis & 560 & 40 & 5.6 & 1.603 & 0.903 \\
\hline 2 & Q9Y3V2 & RWD domain-containing protein 3 & C & Protein binding & 400 & 30 & 6 & 1.589 & 0.857 \\
\hline 3 & P38646 & Stress-70 protein & M & Anti-apoptosis & 67833 & 73 & 5.9 & 0.555 & 1.026 \\
\hline 4 & Q9UJX0 & Oxidative stress-induced growth inhibitor 1 & C & Ccell growth & 112 & 60 & 7 & 3.456 & 0.47 \\
\hline 5 & 075439 & $\begin{array}{l}\text { Mitochondrial-processing peptidase subunit } \\
\text { beta }\end{array}$ & M & Proteolysis & 138 & 54 & 6.4 & 0.331 & 1.597 \\
\hline 6 & 075208 & Ubiquinone biosynthesis protein COQ9 & M & $\begin{array}{l}\text { Ubiquinone } \\
\text { biosynthesis }\end{array}$ & 151 & 35 & 5.6 & 0.615 & 1.579 \\
\hline 7 & Q99518 & Dimethylaniline monooxygenase & ER & Oxidoreductase & 161 & 60 & 8.6 & 0.434 & 1.571 \\
\hline 8 & P10809 & $60 \mathrm{kDa}$ heat shock protein & M & Chaperone & 730 & 61 & 5.7 & 0.553 & 1.094 \\
\hline 9 & Q8N987 & $\mathrm{N}$-terminal EF-hand calcium-binding protein 1 & C & Calcium ion binding & 404 & 40 & 4.8 & 1.7 & 0.229 \\
\hline 10 & Q96AB6 & Protein $\mathrm{N}$-terminal asparagine amidohydrolase & C & Hydrolase & 112 & 34 & 5.8 & 0.235 & 0.688 \\
\hline 11 & P08754 & $\begin{array}{l}\text { Guanine nucleotide-binding protein } \mathbf{G}(\mathbf{k}) \\
\text { subunit alpha }\end{array}$ & C & Transducer & 1704 & 40 & 5.5 & 1.631 & 0.782 \\
\hline 12 & P27797 & Calreticulin precurso & ER & $\begin{array}{l}\text { Signal transducer } \\
\text { activity }\end{array}$ & 183 & 48 & 4.3 & 2.225 & 0.362 \\
\hline 13 & Q9H361 & Polyadenylate-binding protein 3 & C & Poly(A) RNA binding & 156 & 70 & 9.7 & 8.041 & 0.25 \\
\hline 14 & Q6IQ49 & Uncharacterized protein C1orf55 & Unknown & Unknown & 4333 & 49 & 5.8 & 0.45 & 1.604 \\
\hline 15 & Q9NPA1 & $\begin{array}{l}\text { Calcium-activated potassium channel subunit } \\
\text { beta-3 }\end{array}$ & CM & Transport & 920 & 31 & 6.9 & 0.589 & 2.289 \\
\hline 16 & Q9Y603 & Transcription factor ETV7 & $\mathrm{N}$ & Repressor & 142 & 38 & 8.3 & 3.929 & 0.39 \\
\hline 17 & Q17RB8 & $\begin{array}{l}\text { LON peptidase } \mathrm{N} \text {-terminal domain and RING } \\
\text { finger protein } 1\end{array}$ & $M$ & Proteolysis & 133 & 47 & 5.6 & 0.614 & 1.261 \\
\hline 18 & P35232 & Prohibitin & $M$ & DNA replication & 1501 & 29 & 5.6 & 0.567 & 1.581 \\
\hline 19 & Q9Y262 & $\begin{array}{l}\text { Eukaryotic translation initiation factor } 3 \\
\text { subunit E-interacting protein }\end{array}$ & C & Initiation factor & 1001 & 66 & 5.9 & 1.623 & 1.01 \\
\hline 20 & Q9Y512 & $\begin{array}{l}\text { Sorting and assembly machinery component } \\
50 \text { homolog }\end{array}$ & $M$ & Protein binding & 303 & 51 & 6.4 & 0.194 & 0.632 \\
\hline 21 & Q9Y3Q3 & $\begin{array}{l}\text { Transmembrane emp24 domain-containing } \\
\text { protein } 3 \text { precursor }\end{array}$ & G & Transport & 1306 & 24 & 5.4 & 0.532 & 1.024 \\
\hline 22 & Q15080 & Neutrophil cytosol factor 4 & C & Immune response & 116 & 39 & 6.4 & 0.352 & 0.985 \\
\hline 23 & Q12792 & Twinfilin-1 & C & $\begin{array}{l}\text { Regulation of actin } \\
\text { phosphorylation }\end{array}$ & 177 & 42 & 6.5 & 0.03 & 2.558 \\
\hline 24 & P31321 & $\begin{array}{l}\text { cAMP-dependent protein kinase type I-beta } \\
\text { regulatory subunit }\end{array}$ & C & $\begin{array}{l}\text { Transmembrane } \\
\text { transport }\end{array}$ & 219 & 43 & 5.6 & 0.504 & 1.865 \\
\hline 25 & Q15080 & Neutrophil cytosol factor 4 & C & Immune response & 104 & 39 & 6.4 & 0.881 & 1.703 \\
\hline 26 & Q8N3R9 & MAGUK p55 subfamily member 5 & C & Tight junction assembly & 3244 & 77 & 5.8 & 4.311 & 1.148 \\
\hline 27 & P06753 & Tropomyosin alpha-3 chain & C & Actin binding & 179 & 32 & 4.7 & 1.534 & 0.473 \\
\hline 28 & P14550 & Alcohol dehydrogenase & C & Oxidoreductase & 173 & 36 & 6.3 & 1.722 & 0.876 \\
\hline 29 & Q5TZF3 & Ankyrin repeat domain-containing protein 45 & C & Unknown & 2335 & 31 & 4.6 & 0.739 & 2.151 \\
\hline 30 & Q16222 & UDP-N-acetylhexosamine pyrophosphorylase & C & Transferase & 193 & 58 & 5.9 & 4.854 & 0.304 \\
\hline 31 & P04083 & Annexin A1 & C & Anti-apoptosis & 271 & 38 & 6.6 & 0.6 & 1.442 \\
\hline 32 & P51580 & Thiopurine S-methyltransferase & C & Transferase & 150 & 28 & 5.8 & 0.051 & 1.518 \\
\hline 33 & 014618 & Copper chaperone for superoxide dismutase & C & Chaperone & 137 & 29 & 5.3 & 0.423 & 1.27 \\
\hline
\end{tabular}

${ }^{a}$ The Swiss-Prot/TrEMBL database accession number. ${ }^{b}$ protein score greater than 100 are significant $(p<0.05)$. CM: Cell membrane, ER: Endoplasmic reticulum, M: Mitochondrion, N: Nucleus, C: Cytoplasm, G: Golgi apparatus, L: Lysosome, S: Secreted, MC: Microtubule. 


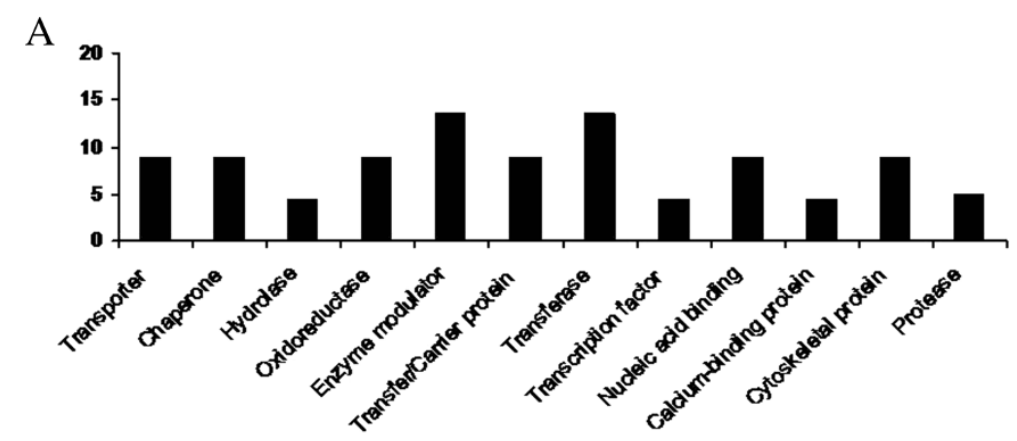

B

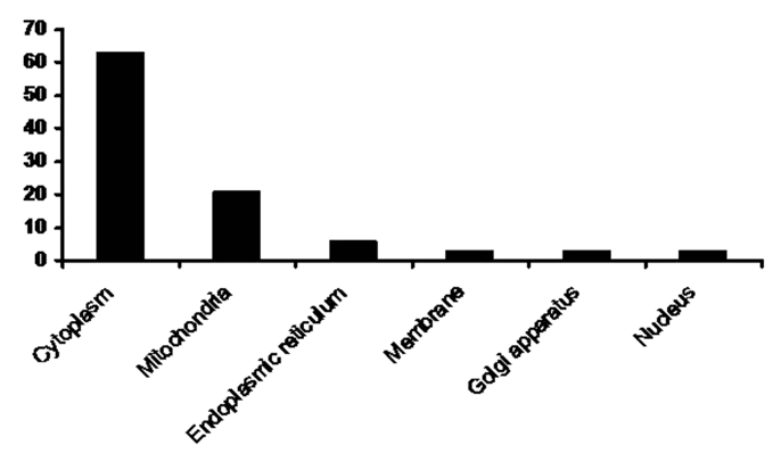

Figure 2 Classification of the proteins showing differential expression. Bar graph representing the distribution of the 33 identified proteins according to their biological function, panel $\boldsymbol{A}$, and cellular localization, panel $\boldsymbol{B}$. Assignments were made based on information from the NCBI (www.ncbi.nlm.nih.gov/PubMed) and the Swiss-Prot/TrEMBL protein knowledgebase (http://au.expasy.org/sport) websites.

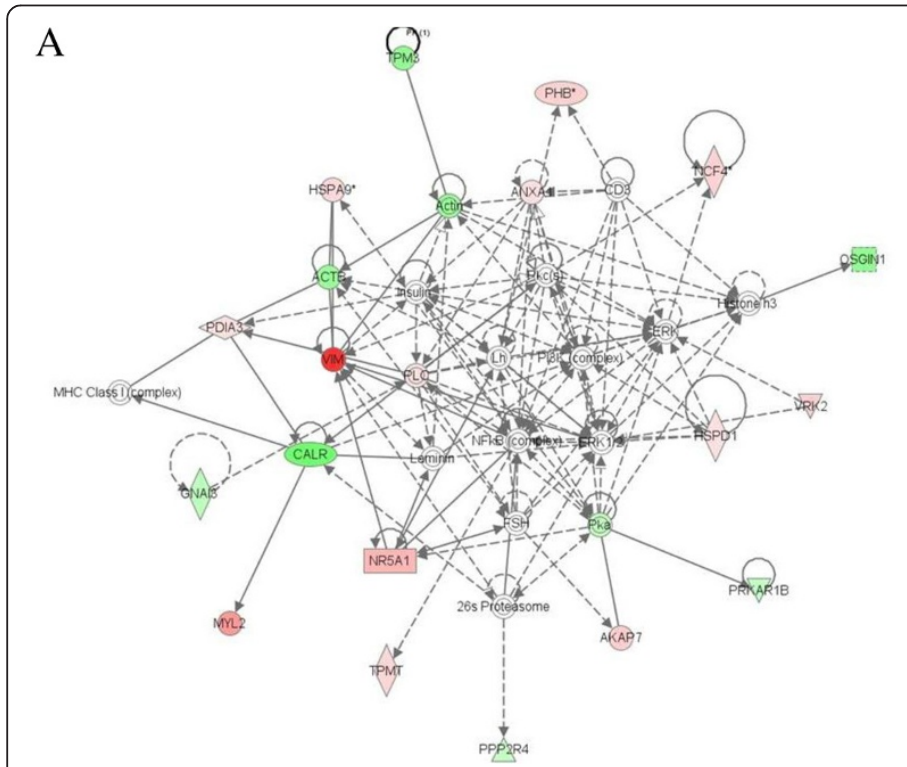

\section{B}

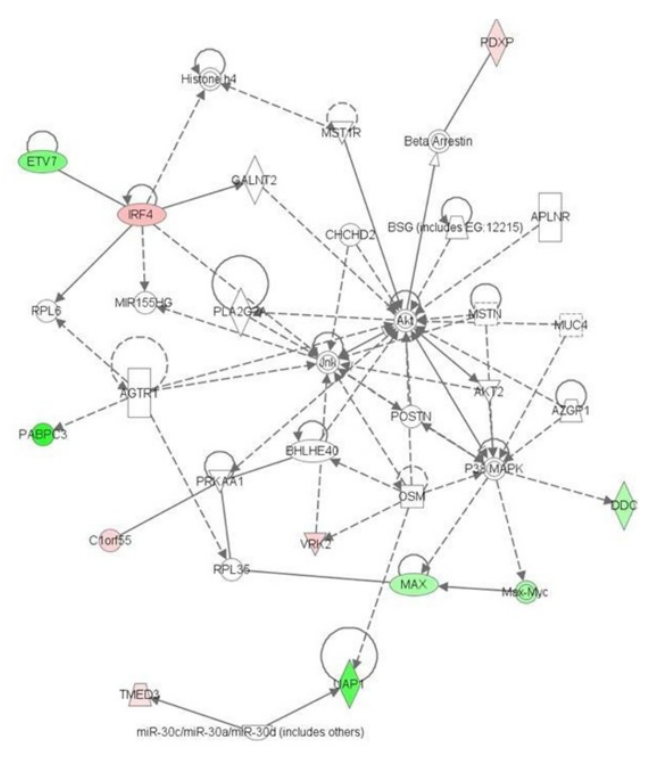

Figure 3 Network pathway analysis of the differential expressed proteins melittin treatment. Proteins are grouped as being (A) primarily involved in lipid metabolism, small molecule biochemistry, cellular movement, (B) primarily involved in developmental disorder, skeletal and muscular disorders, cancer. Proteins shaded in red showed $a \geq 1.5$-fold increase in abundance in melittin treated cells. Proteins shaded in green showed $a \leq 0.6$-fold decrease in abundance in melittin treated cells. The color intensity denotes the degree of abundance. Proteins were identified through the ingenuity Knowledge Base. The shapes denote the molecular class of the protein. Solid line indicates a direct molecular interaction. 


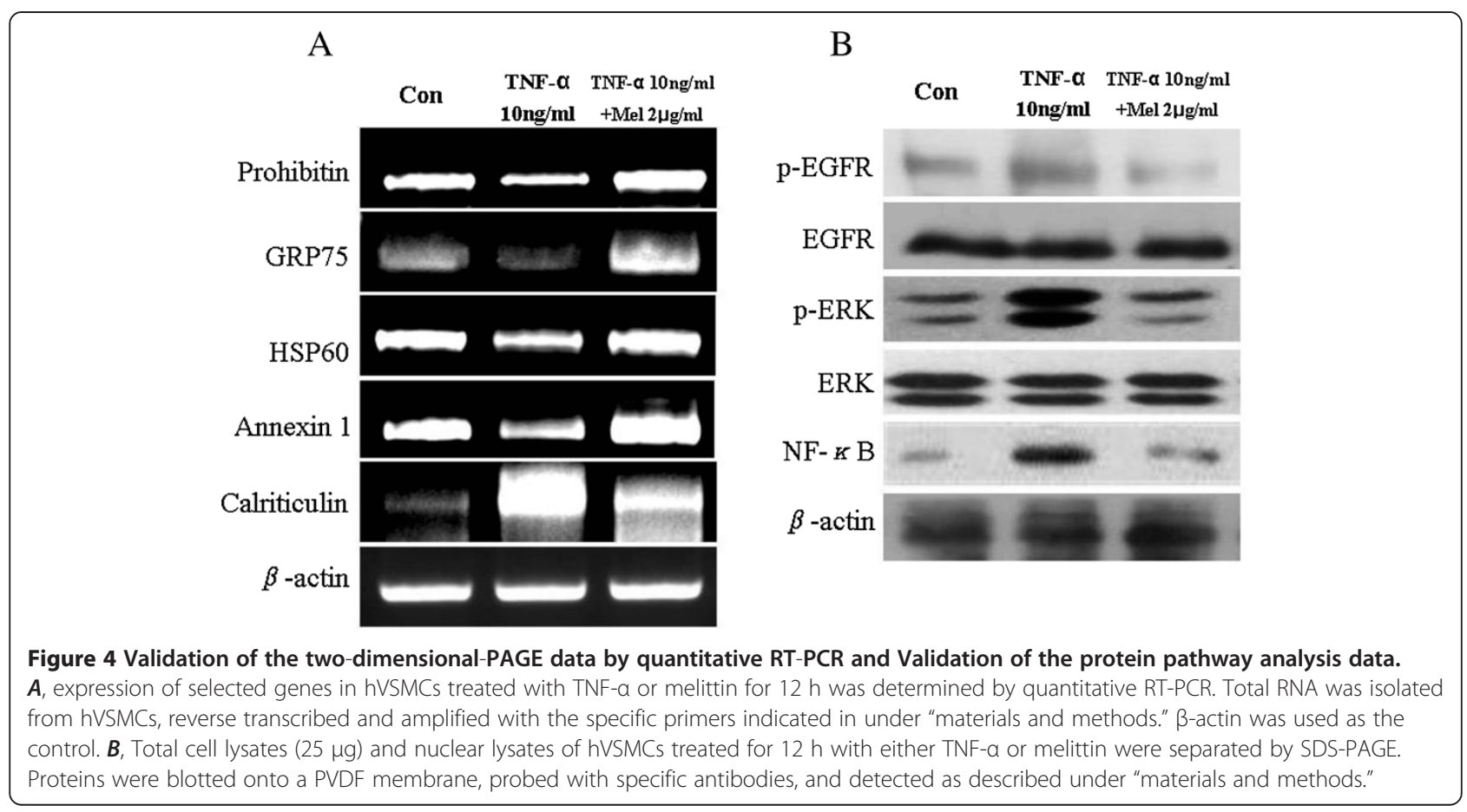

pathway analysis showed that NF- $\mathrm{BB}$, and EGFR are the main molecular of inflammation in hVSMCs treated with TNF- $\alpha$ or melittin. It was consistent with other study. Jijon $\mathrm{HB}$ et al. reported that TNF- $\alpha$ induced ERK and EGFR activation [29] and Andrianifahanana $M$ et al. reported that TGF- $\beta$ induced EGFR activation [30]. According these reports, we suggest that TNF- $\alpha$ induced ERK/NF-kb and EGFR. We believe that this experiment would improve understanding of the anti-inflammatory effects of melittin on inflammatory disease, and atherosclerosis.

\section{Methods}

Cell culture and biological reagents

Human Vascular Smooth Muscle Cells (hVSMCs) were obtained from the American Type Culture Collection (Manassas, VA, USA). Cells were cultured in RPMI medium (Invitrogen, Gland island, USA) containing 10\% fetal bovine serum. The cells were maintained at $37^{\circ} \mathrm{C}$. The hVSMCs were grown on culture plates to $60 \%-70 \%$ confluence in complete medium containing 10\% FBS for 12 hours, and then changed to serum-free medium after washing twice with medium. Then, the cells were incubated with TNF- $\alpha$ or melittin at various concentrations.

\section{Protein extraction and Two-dimensional gel electrophoresis}

hVSMCs were washed three times with ice-cold PBS. Cells were lysed with a buffer containing $5 \mathrm{mM}$ EDTA, 9.5 M urea, 4\% (v/v) CHAPS, $65 \mathrm{mM}$ DTT and protease inhibitors (Complete kit, Roche Diagnostics, Germany) for $1 \mathrm{~h}$ at $24^{\circ} \mathrm{C}$. Cellular debris was removed by centrifugation for $15 \mathrm{~min}$ at $20000 \times g$ at $4^{\circ} \mathrm{C}$. Protein samples were stored at $-70^{\circ} \mathrm{C}$. Protein concentrations were quantified using a commercial Bradford Kit (DC reagent kit, Bio-Rad).

2-D electrophoresis was performed using an established procedure [31]. Whole cell lysate $(400 \mu \mathrm{g})$ was added to immobilized $\mathrm{pH}$ 3-10 linear gradient strips (ReadyStrip IPG strip, Bio-Rad). After finished IEF, the IPG strips were incubated in equilibration buffer containing 37.5 $\mathrm{mM}$ Tris- $\mathrm{HCl}$ (pH 8.8), $6 \mathrm{M}$ urea, 2\% (w/vol) SDS, 30\% $(\mathrm{v} / \mathrm{v})$ glycerol and $2 \%(\mathrm{w} / \mathrm{vol})$ DTT or $2.5 \%$ (w/vol) iodoacetamide for $30 \mathrm{~min}$. The equilibrated IPG strips were transferred onto $12 \%$ Duracryl gels $(180 \times 160 \times$ $1.5 \mathrm{~mm}$ ) for SDS-PAGE. We stained gels with sensitive colloidal coomassie G-250 according to Neuhoff et al. [32]. To check the reproducibility of the data, three independent experiments were performed on each cell lysate. For the differential analysis, statistical significance was estimated with Student's $t$-test. Values of $p<0.05$ were considered significant.

\section{Protein identification}

Protein identification was performed as described previously study [33]. In brief, proteins were in-gel digested with trypsin and extracted from coomassie stained 2-D gel pieces in according to standard procedures. After ingel digested, the peptides were extracted twice with $0.1 \%$ TFA in 50\% acetonitrile. Extracts were pooled and lyophilized. The resulting lyophilized tryptic peptides were concentrated and desalted by passing them through 
C18ZipTip (Millopore, Billerica, MA, USA) following standard procedures. MS analysis was conducted with a MALDI-TOF-TOF mass spectrometer 4700 Proteomics Analyzer (Applied Biosystems, Framingham, MA, USA). Data were analyzed using GPS Explorer software (Applied Biosystem) and MASCOT software (Matrix Science, London, UK). NCBInr and human were selected as the database and taxonomy, respectively. Identification was assigned to a protein spot feature if the protein score was calculated to be greater than 50 , correlating to a confidence interval of $99 \%$.

\section{Protein pathway analysis}

After protein identification, the accession numbers and fold changes of the differentially expressed proteins were tabulated in Microsoft Excel and imported into IPA (Ingenuity System, Montain View, CA, USA). IPA is a software application that enables to identify the biological mechanisms, pathways and functions matching a particular dataset of proteins. IPA is based on a database obtained by abstracting and interconnecting a large fraction of the biomedical literature according to a very strict algorithm. This database integrates protein functions, cellular localization, small molecules and disease inter-relationships. The networks are displayed graphically as nodes, representing individual proteins and edges representing the biological relation between nodes. Using IPA, Canonical pathway analysis utilizes well characterized metabolic and cell signaling pathways which are generated prior to data input and on which identified proteins are overlaid.

\section{Western blot analysis}

Whole cell and nuclear lysates were prepared as previously described [31]. Cells were lysed with RIPA buffer. (50 mM Tris, $150 \mathrm{mM} \mathrm{NaCl}, 1 \mathrm{mM}$ EDTA, $1 \mathrm{mM}$ DTT, $0.5 \%[\mathrm{v} / \mathrm{v}] \mathrm{NP} 4010 \mathrm{mM} \mathrm{NaF}$ and proteases inhibitors). The cells were disrupted and proteins were extracted at $4^{\circ} \mathrm{C}$ for $30 \mathrm{~min}$. The proteins were electro transferred to PVDF membranes (Invitrogen). Detection of specific proteins was carried out with an enhanced chemiluminescence western blotting kit following the manufacturer's (Pierce) instructions. Antibodies specific for p-ERK, ERK, EGFR, p-EGFR, NF- $\mathrm{BB}$ and $\beta$-actin were purchased from Santa Cruz Biotechnology (Santa Cruz, CA).

\section{Reverse transcribed-PCR-analysis}

After treatment of cells with TNF- $\alpha$ or melittin, Total RNA was isolated from each preparation using the Trizol reagent (Invitrogen, Carlsbad, CA). Reverse transcription was carried out using a commercial kit (Superscript II RNase H-reverse transcriptase, Invitrogen) and total RNA (1 $\mu \mathrm{g}$ ) from hVSMCs, according to the manufacturer's protocol. Gene expression was analyzed using specific primers. Amplified products were resolved by $1.0 \%(\mathrm{w} / \mathrm{v})$ agarose gel electrophoresis and visualized by staining with ethidium bromide. We quantified the actual mRNA level of each gene by using Eagle Sight densitometry software (Version 3.21; Stratagene, La Jolla, CA).

\section{Additional file}

\begin{abstract}
Additional file 1: Validation of the two-dimensional-PAGE data by quantitative RT-PCR and validation of protein pathway analysis data. $\boldsymbol{A}$, expression of selected genes in hVSMCs respectively treated with TNF- $\mathrm{a}$ and melittin for $12 \mathrm{~h}$ was determined by quantitative RT-PCR. Total RNA was isolated from hVSMCs, reverse transcribed and amplified with the specific primers indicated in under "Materials and methods." $\beta$-actin was used as the control. $\boldsymbol{B}$, Total cell lysates $(25 \mu \mathrm{g})$ and nuclear lysates $(40 \mu \mathrm{g})$ of hVSMCs respectively treated for $12 \mathrm{~h}$ with TNF- $\mathrm{a}$ and melittin were separated by SDS-PAGE. Proteins were blotted onto a PVDF membrane, probed with specific antibodies, and detected as described under "materials and methods."
\end{abstract}

\section{Competing interests}

The authors declare that they have no competing interests.

\section{Authors' contributions}

HJC and JHK performed proteomic analysis including its design, coordination, analysis of the data, and drafted the manuscript. All authors read and approved the final manuscript.

\section{Acknowledgements}

This work was supported by a grant (PJ00953402) from Biogreen 21 Program, Rural Development Administration, Republic of Korea and also by the National Research Foundation of Korea (NRF, Personalized Tumor Engineering Research Center) grant funded by the Korea government (MEST) (NO. 2012-0000481)

\section{Author details}

${ }^{1}$ Research Institute of Biomedical Engineering and Department of Medicine, Catholic University of Daegu School of Medicine, Daegu 705-718, Republic of Korea. '2Laboratory of Cell Biology, NCl, National Institutes of Health, Bethesda, MD 20892, USA. ${ }^{3}$ Department of Biotechnology, Catholic University of Daegu, Gyeongsan 712-702, Republic of Korea. ${ }^{4}$ College of Pharmacy, Yeungnam University, Gyeongsan 712-749, Republic of Korea. ${ }^{5}$ Department of Biological Science, Sungkyunkwan University, Sungkyunkwan, Kyunggi-Do 440-746, Republic of Korea. ${ }^{6}$ Department of Biochemistry, College of Oriental Medicine, Dongeui University, Busan 614-052, Republic of Korea.

${ }^{7}$ Personalized Tumor Engineering Research Center, Department of Urology, Chungbuk National University, Cheongju, Chungbuk 361-763, Republic of Korea. ${ }^{8}$ Department of Food Science and Technology, Chung-Ang University, Ansung 456-756, Republic of Korea.

Received: 16 October 2012 Accepted: 1 May 2013 Published: 7 May 2013

\section{References}

1. Jeong YJ, Cho HJ, Whang K, Lee IS, Park KK, Choe JY, Han SM, Kim CH, Chang HW, Moon SK, et al: Melittin has an inhibitory effect on TNF-alpha-induced migration of human aortic smooth muscle cells by blocking the MMP-9 expression. Food Chem Toxicol 2012, 50:3996-4002.

2. Gerthoffer WT: Mechanisms of vascular smooth muscle cell migration. Circ Res 2007, 100:607-621.

3. Goetze S, Xi XP, Kawano Y, Kawano H, Fleck E, Hsueh WA, Law RE: TNF-alpha-induced migration of vascular smooth muscle cells is MAPK dependent. Hypertension 1999, 33:183-189.

4. Billingham ME, Morley J, Hanson JM, Shipolini RA, Vernon CA: Letter: an anti-inflammatory peptide from bee venom. Nature 1973, 245:163-164.

5. Kwon YB, Lee HJ, Han HJ, Mar WC, Kang SK, Yoon OB, Beitz AJ, Lee JH: The water-soluble fraction of bee venom produces antinociceptive and anti- 
inflammatory effects on rheumatoid arthritis in rats. Life Sci 2002, 71:191-204.

6. Kwon YB, Lee JD, Lee HJ, Han HJ, Mar WC, Kang SK, Beitz AJ, Lee JH: Bee venom injection into an acupuncture point reduces arthritis associated edema and nociceptive responses. Pain 2001, 90:271-280.

7. Li B, Gu W, Zhang C, Huang XQ, Han KQ, Ling CQ: Growth arrest and apoptosis of the human hepatocellular carcinoma cell line BEL-7402 induced by melittin. Onkologie 2006, 29:367-371.

8. Orsolic N, Sver L, Verstovsek S, Terzic S, Basic I: Inhibition of mammary carcinoma cell proliferation in vitro and tumor growth in vivo by bee venom. Toxicon 2003, 41:861-870

9. Perez-Paya E, Houghten RA, Blondelle SE: The role of amphipathicity in the folding, self-association and biological activity of multiple subunit small proteins. J Biol Chem 1995, 270:1048-1056.

10. Meier JWJ: Clinical toxicology of animal venoms and poisons. Boca Raton: CRC Press; 1995.

11. Raghuraman $\mathrm{H}$, Chattopadhyay A: Melittin: a membrane-active peptide with diverse functions. Biosci Rep 2007, 27:189-223.

12. Duke RC, Witter RZ, Nash PB, Young JD, Ojcius DM: Cytolysis mediated by ionophores and pore-forming agents: role of intracellular calcium in apoptosis. FASEB J 1994, 8:237-246.

13. Wang C, Chen T, Zhang N, Yang M, Li B, Lu X, Cao X, Ling C: Melittin, a major component of bee venom, sensitizes human hepatocellular carcinoma cells to tumor necrosis factor-related apoptosis-inducing ligand (TRAIL)-induced apoptosis by activating CaMKII-TAK1-JNK/p38 and inhibiting IkappaBalpha kinase-NFkappaB. J Biol Chem 2009, 284:3804-3813.

14. Lubke $L L$, Garon CF: The antimicrobial agent melittin exhibits powerful in vitro inhibitory effects on the Lyme disease spirochete. Clin Infect Dis 1997, 25(Suppl 1):S48-51.

15. Lazarev VN, Shkarupeta MM, Titova GA, Kostrjukova ES, Akopian TA, Govorun VM: Effect of induced expression of an antimicrobial peptide melittin on Chlamydia trachomatis and Mycoplasma hominis infections in vivo. Biochem Biophys Res Commun 2005, 338:946-950

16. Wang S, Fusaro G, Padmanabhan J, Chellappan SP: Prohibitin co-localizes with $\mathrm{Rb}$ in the nucleus and recruits $\mathrm{N}-\mathrm{CoR}$ and $\mathrm{HDAC} 1$ for transcriptional repression. Oncogene 2002, 21:8388-8396.

17. Sharma A, Qadri A: Vi polysaccharide of Salmonella typhi targets the prohibitin family of molecules in intestinal epithelial cells and suppresses early inflammatory responses. Proc Natl Acad Sci U S A 2004, 101:17492-17497.

18. Nijtmans $L G$, de Jong $L$, Artal Sanz M, Coates PJ, Berden JA, Back JW, Muijsers AO, van der Spek H, Grivell LA: Prohibitins act as a membranebound chaperone for the stabilization of mitochondrial proteins. EMBO J 2000, 19:2444-2451.

19. Joshi B, Rastogi S, Morris M, Carastro LM, DeCook C, Seto E, Chellappan SP Differential regulation of human YY1 and caspase 7 promoters by prohibitin through E2F1 and p53 binding sites. Biochem J 2007, 401:155-166.

20. Jupe ER, Liu XT, Kiehlbauch JL, McClung JK, Dell'Orco RT: Prohibitin antiproliferative activity and lack of heterozygosity in immortalized cell lines. Exp Cell Res 1995, 218:577-580.

21. Dell'Orco RT, McClung JK, Jupe ER, Liu XT: Prohibitin and the senescent phenotype. Exp Gerontol 1996, 31:245-252.

22. Hsieh SY, Shih TC, Yeh CY, Lin CJ, Chou YY, Lee YS: Comparative proteomic studies on the pathogenesis of human ulcerative colitis. Proteomics 2006, 6:5322-5331.

23. Theiss AL, Idell RD, Srinivasan S, Klapproth JM, Jones DP, Merlin D, Sitaraman SV: Prohibitin protects against oxidative stress in intestinal epithelial cells. FASEB J 2007, 21:197-206

24. Moss SE, Morgan RO: The annexins. Genome Biol 2004, 5:219.

25. Haigler HT, Christmas P: Annexin 1 is secreted by the human prostate. Biochem Soc Trans 1990, 18:1104-1106.

26. Lim LH, Solito E, Russo-Marie F, Flower RJ, Perretti M: Promoting detachment of neutrophils adherent to murine postcapillary venules to control inflammation: effect of lipocortin 1. Proc Natl Acad Sci U S A 1998, 95:14535-14539.

27. Zhu J, Newkirk MM: Viral induction of the human autoantigen calreticulin. Clin Invest Med 1994, 17:196-205.

28. Kishore U, Sontheimer RD, Sastry KN, Zaner KS, Zappi EG, Hughes GR, Khamashta MA, Strong P, Reid KB, Eggleton P: Release of calreticulin from neutrophils may alter C1q-mediated immune functions. Biochem J 1997, 322(Pt 2):543-550

29. Jijon HB, Buret A, Hirota CL, Hollenberg MD, Beck PL: The EGF receptor and HER2 participate in TNF-alpha-dependent MAPK activation and IL-8 secretion in intestinal epithelial cells. Mediators Inflamm 2012, 207398.

30. Andrianifahanana M, Wilkes MC, Repellin CE, Edens M, Kottom TJ, Rahimi RA, Leof EB: ERBB receptor activation is required for profibrotic responses to transforming growth factor beta. Cancer Res 7430, 70:7421-7430.

31. Kang JH, Kim HT, Choi MS, Lee WH, Huh TL, Park YB, Moon BJ, Kwon OS: Proteome analysis of human monocytic THP-1 cells primed with oxidized low-density lipoproteins. Proteomics 2006, 6:1261-1273.

32. Neuhoff $V$, Arold N, Taube D, Ehrhardt W: Improved staining of proteins in polyacrylamide gels including isoelectric focusing gels with clear background at nanogram sensitivity using Coomassie Brilliant Blue G-250 and R-250. Electrophoresis 1988, 9:255-262.

33. Kang JH, Chang YC, Maurizi MR: 4-O-carboxymethyl ascochlorin causes ER stress and induced autophagy in human hepatocellular carcinoma cells. J Biol Chem 2012, 287:15661-15671.

doi:10.1186/1477-5956-11-20

Cite this article as: Cho et al: Comparative proteome analysis of Tumor necrosis factor a-stimulated human Vascular Smooth Muscle Cells in response to melittin. Proteome Science 2013 11:20.

\section{Submit your next manuscript to BioMed Central and take full advantage of:}

- Convenient online submission

- Thorough peer review

- No space constraints or color figure charges

- Immediate publication on acceptance

- Inclusion in PubMed, CAS, Scopus and Google Scholar

- Research which is freely available for redistribution 